\title{
Increasing of Nutritional and Added Values of Functional Kishk by Replacing Burghul with Broken Seeds of Faba Bean (Vicia Faba, L.) as Innovative Dairy Product
}

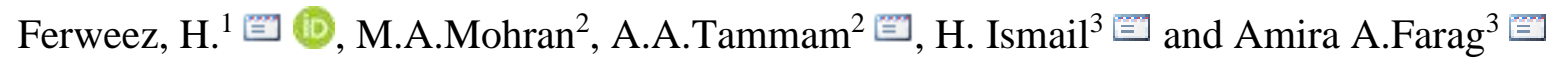 \\ ${ }^{1}$ Food Sci. and Tech. Dept., Faculty of Agric., New Valley Univ., Egypt \\ ${ }^{2}$ Dariy Dept., Faculty of Agric., Assiut Univ., Egypt \\ ${ }^{3}$ Dariy Dept., Faculty of Agric., New Valley Univ., Egypt
}

"Correspondence author

Received: 10/11/2021

Revised: 30/11/2021

Accepted: $10 / 12 / 2021$

Published: $14 / 12 / 2021$

\section{Abstract}

Kishk is a natural functional food as minor constituents that are deficient in milk are supplemented by cereals. It also widely consumed in the diet of many people in the Middle East, especially Upper Egypt. This work was conducted at Dairy Department laboratories, Faculty of Agriculture, New Valley University as well as laboratories of Agricultural Research Center, Giza, Egypt. The aim of this paper is to investigate replacing bulgur by different percent of broken faba bean seeds (by-product) and type of milk on compositional, nutritional, microbiological, and sensory qualities of Saidy kishk to increase the added value viewpoint of economical and nutritional. The results indicated that there were a significant differences in physiochemical properties, i.e. moisture, ash, protein, fat, carbohydrates contents, $\mathrm{pH}$ and titratable acidity, essential amino acids, mineral contents such as $\mathrm{Ca}, \mathrm{Mg}, \mathrm{K}, \mathrm{Na}, \mathrm{P}$ and $\mathrm{Fe}$, microbiological properties, TBC and LAB as well as sensory properties of Saidy Kishk samples as a result of replacing bulgur by different percent of broken faba bean seeds by 25 and $50 \%$ or change the studied milk type, i.e. full cow milk, skimmed milk or Laban zeer. This study concluded that Saidy Kishk samples manufactured from $50 \%$ B $+50 \%$ Fb with skimmed milk had the highest values of threonine (3.75\%), leucine (10.91\%), lysine $(6.47 \%)$, phenylalanine (5.33\%), valine (4.88\%), histidine (3.11\%), Ca (319.67mg), $\mathrm{Mg}$ (172.00mg), K $(1117.67 \mathrm{mg} / 100 \mathrm{~g} \mathrm{DWB})$ and Fe $(7.19 \mathrm{ppm})$. Therefore, it is suggested that this formula of Saidy Kishk samples could be used to increase the added value viewpoint of economical and nutritional.

Keywords: Kishk, Burghul, faba bean, nutritional and sensory quality. 


\section{Introduction}

Dairy products and cereals constitute two of the major food groups. They are frequently combined in many foods, including cereal yoghurts, fortified blended foods (FBFs) and kishk. Throughout the different world regions, there were a lot of fermented milks is manufactured with around 400 generic names. Some are similar, but named differently according to the country, the final texture of these fermented milks, the type of milk used and its composition (Abd El-Salam, 2003; Beal \& Sodini, 2003 Luquet \& Corrieu, 2005 and Tamime \& Robinson, 2006). Cereals and fermented milks are systematically the two main ingredients, but methods of preparation vary among countries and regions. Different types of milks such as cow and buffalo can be used to produce kishk. It is a balanced food as minor constituents that are deficient in milk are supplemented by cereals (Tamer et al., 2007). Kishk plays an important role in the diet, due to its high nutritional value and long shelf life. Dried kishk is not hygroscopic and can be stored in an open jar for two years without spoilage (Abou-Donia, 2008; Yildiz, 2016; Salameh \& Hosri, 2016, and AbouZeid, 2016). It is typically prepared from yogurt (cow, goat, sheep, skim, zeer or buffalo milk), parboiled cracked wheat (bulgur) (ratio bulgur: yogurt 1:4) and salt. Cereals and products of dairy constitute two of the major food groups (Shevade et al., 2018 and Hassan, 2019). They reported that Faba bean seeds contain $20.0-41.0 \%$ protein, $51.0-68.0 \%$ carbohydrates, $12 \%$ fiber, $2.20-2.63$ ash and $1.2-4 \%$ lipids. Dietary fiber ranges between 15.0 and $30.0 \%$, which depends on the seed variety. Faba beans contributed to human nutrition because of its high protein content, and essential nutrients. It is considered as one of the main sources of cheap protein and energy in Africa. Most of these proteins comprise of globulins (79\%), albimins (7\%), and glutelins (6\%) (El.Fiel et al., 2002).

Mohammed et al., (2020) indicated that Legumes (poor man's meat) play an important role in human nutrition since they are rich sources of protein, calories, minerals, and vitamins and therefore can be good supplements. Faba bean (Vicia faba, L.) is the most cultivated leguminous species in the world. Legumes are an important component of traditional diets of several regions all over the world as they are low in fat, rich in protein, dietary fiber and a variety of micronutrients and phytochemicals. Egypt is one of the largest consumers of pulses in the world. They reported that Common bean is a valuable protein source for people of developing countries. Zmudzi et al., (2021) reported that the proteins of Vicia faba, L. presented in seeds consist of two main fractions: albumin, rich in sulfur amino acids and lysine, along with globulins, consisting of convicilin, vicilin, and legumin. The isoelectric point of the Vicia faba, L. proteins is around $\mathrm{pH} 4.0$ where the solubility is the lowest, but with increasing the $\mathrm{pH}$, the solubility constantly increases reaching a maximum at $\mathrm{pH}$ 8.0. Consequently, The objective of the current study was to investigate replacing bulgur by different percent of broken faba bean seeds (by- product) and type of milk on compositional, nutritional, microbiological, and sensory qualities of Saidy kishk to increase the added value viewpoint of economical and nutritional.

\section{Materials and Methods}

2.1. Materials: This work was conducted at Dairy Department laboratories, Faculty of Agriculture, New Valley University as well as laboratories of Agricultural Research Center, Giza, Egypt.

1.1. Food ingredients for manufacture of Saidy kishk:

1.1.1. Burghul of wheat, broken seeds of faba bean and salt were purchased from local market from Assuit City, Assuit Governorate, Egypt. Burghul and broken seeds of faba bean were cleaned from straw, dirt and weed seeds, washed using tap water for several times. Then the cereals were heated until boiling for 30 min. Burghul contains total solid $89.39 \%$, protein $10.91 \%$, fat $0.68 \%$, carbohydrate $72.78 \%$, ash $1.85 \%, \mathrm{pH}$ value 6.71 , fiber $1.16 \%, \mathrm{Ca} 80.33, \mathrm{Mg} 77.67, \mathrm{~K} 591, \mathrm{Na} 4.13$, P $384 \mathrm{mg} / 100 \mathrm{~g}$ and Fe $4.29 \mathrm{ppm}$. Also, it contains essential amino acids such as threonine 2.68, isoleucine 2.13, leucine 4.70, 
lysine 2.48 , methionine 0.88 , phenyalanine 2.42 , valine 2.55 , tyrosine 1.62 , tryptophan 0.85 and histidine $1.28 \mathrm{~g} / 100$ proteins. While, broken seeds of faba bean (by-product) from the manufacture of Madshush Bean contains total solid $89.32 \%$, protein $31.41 \%$, fat $2.69 \%$, carbohydrate $51.04 \%$, ash $3.03 \%, \mathrm{pH}$ value 6.84, fiber $0.48 \%$, Ca $105.22, \mathrm{Mg} 208, \mathrm{~K}$ 988.67, $\mathrm{Na} 6.68, \mathrm{P} 503 \mathrm{mg} / 100 \mathrm{~g}$ and $\mathrm{Fe} 6.85$ ppm. Besides, it contains essential amino acids such as threonine 3.82 , isoleucine 4.21 , leucine 7.33 , lysine 6.53 , methionine 0.63 , phenyalanine 4.26 , valine 4.19 , tyrosine 3.49 , tryptophan 0.51 and histidine $2.41 \mathrm{~g} / 100$ protein (DWB).

1.1.2. Cow milk used in preparation of skimmed milk and Laban Zeer was obtained from one of special dairy farms at El-Kharga Oasis, New Valley Governorate, Egypt. Full cow milk, skimmed milk and Laban Zeer were prepared, filtered, and heated to $73^{\circ} \mathrm{C}$ for $15 \mathrm{~s}$ in water bath and cold down to $37{ }^{\circ} \mathrm{C}$. The starter culture (lactic acid bacteria) was added at $1 \%$ under sanitary conditions. Inoculated full cow milk contains total solid $12.80 \%$, protein $3.27 \%$, fat $3.87 \%$, carbohydrate $5.11 \%$, ash $0.62 \%, \mathrm{pH}$ value 6.67 , acidity 1.42 $0.1 \mathrm{~N} \mathrm{NaOH}, \mathrm{Ca} 73, \mathrm{Mg} 57, \mathrm{~K} 145.33, \mathrm{Na}$ 2.09, P $88.00 \mathrm{mg} / 100 \mathrm{~g}$ and Fe $2.09 \mathrm{ppm}$. Inoculated liquid skimmed milk contains fat $0.11 \%, \mathrm{pH}$ value 6.70 , acidity $1.410 .1 \mathrm{~N}$ $\mathrm{NaOH}, \mathrm{Ca} 174.00, \mathrm{Mg} 99.33, \mathrm{~K} 252.00, \mathrm{Na}$ 7.33,P $132.00 \mathrm{mg} / 100 \mathrm{~g}$ and $\mathrm{Fe} 3.23 \mathrm{ppm}$. Inoculated Laban Zeer contains fat $0.69 \%, \mathrm{pH}$ value 3.06 , acidity $1.910 .1 \mathrm{~N} \mathrm{NaOH}, \mathrm{Ca}$ 166.00, Mg 69.00, K 93.00, Na 16.00,P 93.00 $\mathrm{mg} / 100 \mathrm{~g}$ and Fe $2.41 \mathrm{ppm}$ (on DWB). The inoculated milk was left at room temperature for $24 \mathrm{~h}$ until curdling completed. The produced Laban Rayeb or yoghurt was filtered through cheesecloth (double layer) to be concentrated and used in making of the Kishk. Laban Zeer is also known as earthenware stored concentrated butter milk. During hot weather in Upper Egypt, the milk coagulates before the fat is removed. It is then stored in earthenware containers, Zeers, and referred to a Laban Zeer. The Laban Zeer is usually collected from May onwards to be used in the making of Kishk, after harvest of wheat.

1.2. Laboratory-based production of Saidy kishk: Nine laboratory Saidy kishk samples was produced (Table 1) as follows: burghul (parboiled cracked wheat) or formula of burghul with broken seeds of faba bean was mixed with Laban Rayeb or yoghurt prepared from the studied milk type (Full cow milk, skimmed milk, or Laban Zeer) at a ratio of 1:2 (w/w) and incubated at $25{ }^{\circ} \mathrm{C}$ for $36 \mathrm{~h}$. Also, Salt $(1 \%, w / w)$ was added to the formula mixture, and the mixture kneaded to facilitate fermentation. Then, the amount of yoghurt was increased until the ratio reaches 1:4 (w/w) and the mixture were kneaded again. Kishk dough was then cut into small balls, spread over stainless steel trays, and dried in an air oven at $50{ }^{\circ} \mathrm{C}$ for 8 hours. The dry product was ground in a mill, sieved through $1 \mathrm{~mm}$ screen, and stored in glass jars at $4{ }^{\circ} \mathrm{C}$ until tested. Kishk samples were taken for physiochemical analysis, microbiological counts (Total bacterial count, lactic acid bacteria, yeast and mold, coliforms) and sensory evaluation of kishk samples were determined.

2. Analytical methods:

2.1. Composition and nutritional quality analysis: Physiochemical analysis of Saidy kishk, whole broken faba bean seeds flour and burghul samples, i.e., water, ash, protein, fat, carbohydrates contents, $\mathrm{pH}$ and titratable acidity were analyzed by the standard methods described in AOAC, (2017). Total Carbohydrate\% was calculated by the following equation:

Totalcarbohydrate $\%=100($ mositure + fat $\%$ + protein $\%+$ ash $\%$ )

2.2. Mineral contents of Saidy kishk sample: Mineral contents of Saidy Kishk samples such as calcium $(\mathrm{Ca})$, Magnesium $(\mathrm{Mg})$, potassium $(\mathrm{K})$, Sodium $(\mathrm{Na})$, phosphorus $(\mathrm{P})$ and iron (Fe) elements were determined using PerkinElmer Atomic Absorption Spectrophotometer as described in AOAC (2017).

2.3. Essential amino acids contents of Saidy kishk samples: Essential amino acid contents of Saidy Kishk samples, i.e., Threonine, 
Table1: Nine formulas of Saidy kishk manufacture samples.

\begin{tabular}{ll}
\hline No. & Type and percent of cereal and milk \\
\hline 1 & $100 \%$ Burghul $+0.0 \%$ broken seeds of faba bean with full cow milk*,T1. \\
\hline 2 & $75.0 \%$ Burghul $+25.0 \%$ broken seeds of faba bean with full cow milk, T2. \\
\hline 3 & $50.0 \%$ Burghul $+50.0 \%$ broken seeds of faba bean with full cow milk, T3. \\
\hline 4 & $100 \%$ Burghul $+0.0 \%$ broken seeds of faba bean with skimmed milk, T4. \\
\hline 5 & $75.0 \%$ Burghul $+25.0 \%$ broken seeds of faba bean with skimmed milk, T5. \\
\hline 7 & $50.0 \%$ Burghul $+50.0 \%$ broken seeds of faba bean with skimmed milk, T6. \\
\hline 8 & 100\% Burghul $+0.0 \%$ broken seeds of faba bean with Laban Zeer, T7. \\
\hline 9 & $50.0 \%$ Burghul $+25.0 \%$ broken seeds of faba bean with Laban Zeer, T8. \\
\hline$*$
\end{tabular}

Isoleucine, Leucine, Lysine, Methionine, phenylalanine, Valine, Histidine, Tyrosine and Tryptophan were analyzed as described in AOAC (2017) using High Performance Amino Acid Analyzer . Sample (100 mg) was hydrolyzed with $5 \mathrm{~mL}$ of $6 \mathrm{~N} \mathrm{HCl}$ at $1100{ }^{\circ} \mathrm{C}$. 2.4. Enumeration of microorganisms: 10 grams of Saidy kishk was dispersed in $100 \mathrm{~mL}$ peptone water solution and homogenized using a stomacher 400 circulator lab blender and cultured in Petri dishes by the surface plate method as in Nassar et al., (2016). Total count of bacteria (TCB) was enumerated in pour-plates of Plate Count Agar (Oxoid, $\mathrm{CM} 0325)$ after incubation at $37^{\circ} \mathrm{C}$ for 48 hours. Counts of Latic acid bacteria (LAB) were determined on M17 agar, incubated anaerobically at $40^{\circ} \mathrm{C}$ for $48 \mathrm{~h}$. The counts of coliforms were determined using Violet Red Bile Agar $\left(37{ }^{\circ} \mathrm{C}, 24-48 \mathrm{~h}\right)$ and yeasts \& moulds in Yeast Extract Dextrose Chloramphenicol Agar $\left(25^{\circ} \mathrm{C}, 5\right.$ days). All media were purchased from the republic company (Imported from Germen). The plate count agar was examined, and colonies present were counted and recorded after incubation, to get the total colony count in $\mathrm{CFU} / \mathrm{mL}$ and counts were carried out in triplicate.

2.5. Sensory evaluation: A panel between 25 and 50 years old evaluated the sensory properties of Saidy kishk samples and gave scores for taste, appearance, flavor, and texture on a hedonic scale from 1 to 25 . The labeled samples were randomly with threedigit numerical codes. Water was provided to the panelists to rinse their mouths between samples as in Çelik, et al., (2010). for $24 \mathrm{~h}$. The hydrolyzed sample was redissolved in $\mathrm{Na}$ citrate buffer $(\mathrm{pH} 2.2)$ and filtered using a $0.2 \mathrm{~lm}$ membrane filter then injected into the amino acid analyzer. The contents of the various recovered amino acids were presented as grams per $100 \mathrm{~g}$ of protein. 2.6. Statistical analysis: Measurements were performed in triplicate for each sample and mean values and standard errors were reported. Statistical analyses were carried out using Costat software (version 6.400). Oneway analysis of variance (ANOVA) and Tukey HSD test were used to establish the significance of differences among the treatments. Calculations were performed considering statistical significance at 5\% according to Montgomery (2010).

\section{Results and Discussion}

3.1. Compositional and nutritional quality of Saidy Kishk:

3.1.1. Physiochemical properties of Saidy Kishk: It should be clarified from the data obtained in Table, 2 that there were significant differences in physiochemical properties of Saidy Kishk because of replacing bulgur by different percent's of broken faba bean seeds. Results revealed that Saidy Kishk manufactured from 50\% burghul $+50 \%$ broken faba bean seeds $(50 \% \mathrm{~B}+50 \% \mathrm{Fb})$ contained highest values of moisture $(10.89 \%)$, crude protein $(26.62 \%)$, crude fat value (3.73) than wheat burghul. On the other side, the same kishk samples had the lowest values of crude fiber $(0.86 \%)$ and total carbohydrates (49.67\%), whereas, broken faba bean contain the higher values of crude protein $(31.41 \%)$, crude fat $(2.69 \%)$, ash $(3.13 \%)$ and $\mathrm{pH}$ (3.73\%), ash $(8.22 \%)$ and $\mathrm{pH}(6.18)$. This might be due to broken faba bean seeds 
composition seeds composition contain the lower values of crude fiber $(0.48 \%)$ and total carbohydrates $(54.94 \%)$ than burghul (crude fiber, $1.16 \%$ and total carbohydrates, $72.78 \%$ ). Therefore, Saidy Kishk manufactured from $100 \%$ burghul $(100 \% \mathrm{~B})$ contains highest values of crude fiber $(1.08 \%)$ and total carbohydrates (61.25\%). The drying technique and composition of ingredients are the main causes for the variation in moisture content of kishk formulation. These findings might be higher or lower that presented in previous papers (Erkan et al., 2006). These differences in papers might be due to studies explained that region and season responsible for variations in chemical composition of cereal. These results agree with those obtained by Erkaya \& Sengül and (2011) and Atamian et al., (2014). Regarding type of milk used in processing Saidy Kishk, from the data given in Table 2 indicated that there was a significant difference in physiochemical properties of Saidy Kishk samples prepared from the studied different types of milk, i.e., full cow milk, skimmed milk, and Laban Zeer. The highest values of crude protein $(23.50 \%)$, crude fat $(5.09 \%)$ and crude fiber $(1.01 \%)$ were recorded in Saidy Kishk prepared from full cow milk, Saidy Kishk prepared from skimmed milk contained the highest values of moisture (10.66\%), ash (7.59\%), and $\mathrm{pH}$ value (6.71); Saidy Kishk prepared from cow milk scored the highest value of carbohydrate content $(58.25 \%)$. This could be attributed to the variations in the used milk composition in kishk manufacture. Where, full cow ilk contained the highest value of carbohydrate content $(4.69 \%)$. The present findings are in in general agreement with those previously reported by Atamian et al., (2014) and Erkaya \& Sengül, (2011). They demonstrated that milk type affected composition of kishk samples, especially fat content. Moreover, significant interaction was scored between cereal type \& percent and milk type used in processing Saidy Kishk regarding moisture, crude protein, crude fat, ash, carbohydrate, and $\mathrm{pH}$ value except crude fiber of Saidy Kishk as shown in Table 2. Saidy Kishk samples manufactured from $50 \% \mathrm{~B}+50 \% \mathrm{Fb}$ with skimmed milk were characterized by the highest values of crude protein $(28.41 \%)$, ash (8.19\%) and $\mathrm{pH}$ value (6.86). Conversely, the lowest values of crude protein $(16.38 \%)$, ash (6.54\%) and $\mathrm{pH}$ value (3.56) were scored in Saidy Kishk samples manufactured from $100 \%$ B with cow milk, which contained the highest value of carbohydrate $(63.34 \%)$. Such differences might be due to the variations of cereal and milk types of components used in Saidy Kishk manufacture. This trend coincided with the results obtained by Atamian et al., (2014) and Erkaya \& Sengül, (2011).

3.1.2. Essential amino acids composition of Saidy Kishk: Data in Tables 3\&4 indicated that there were significant differences in essential amino acids of Saidy Kishk because of replacing bulgur by different percent of broken faba bean seeds. The highest values of threonine $(3.24 \%)$, isoleucine $(5.26 \%)$, leucine $(10.47 \%)$, lysine $(6.23 \%)$, phenylalanine $(4.94 \%)$, valine $(4.29 \%)$, histidine $(2.57 \%)$ and tyrosine $(2.11 \%)$ were found in Saidy Kishk manufactured from $50 \% \mathrm{~B}+50 \% \mathrm{Fb}$, which contained the lowest value of methionine $(1.78 \%)$. Whereas, it contained the highest value of crude protein (26.62\%) (Table 2) among the studied formulas. Conversely, Saidy Kishk manufactured from $100 \%$ B contained lowest values of threonine $(2.69 \%)$, isoleucine $(4.22 \%)$, leucine $(8.14 \%)$, lysine $(3.00 \%)$, phenylalanine $(4.19 \%)$, valine $(3.63 \%)$, histidine $(2.20 \%)$ and tyrosine $(1.54 \%)$, however, it scored the highest value (1.93\%) of methionine. This could be attributed to the amino acid profile is quite different between broken faba bean seeds and burghul. Where, broken faba bean seeds composition had the higher values of threonine (3.82\%), isoleucine $(4.21 \%)$, leucine $(7.33 \%)$, lysine $(6.53 \%)$, 
Table 2: Effect of replacing bulgur by percent of broken faba bean seeds on physicochemical properties of Saidy kishk manufactured from different types of milk.

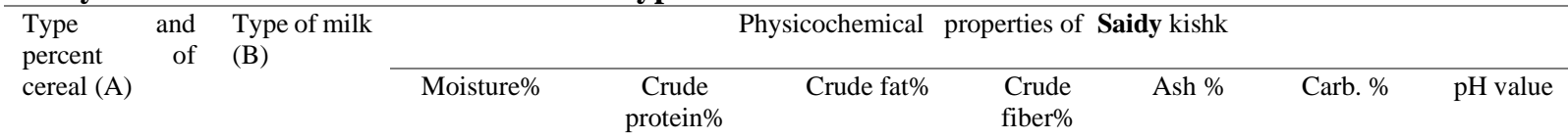

\begin{tabular}{|c|c|c|c|c|c|c|c|c|}
\hline \multirow[t]{3}{*}{ Burghul 100\% } & Cow milk & $9.85^{\mathrm{h}}$ & $17.79^{h}$ & $4.59^{c}$ & 1.11 & $6.43^{\mathrm{i}}$ & $63.34^{\mathrm{a}}$ & $6.46^{\mathrm{f}}$ \\
\hline & $\begin{array}{l}\text { Skimmed } \\
\text { milk }\end{array}$ & $10.06^{\mathrm{g}}$ & $18.27^{\mathrm{g}}$ & $1.73^{\mathrm{i}}$ & 1.04 & $6.78^{g}$ & $61.31^{\mathrm{b}}$ & $6.54^{e}$ \\
\hline & Laban Zeer & $9.72^{i}$ & $16.38^{\mathrm{i}}$ & $1.91^{\mathrm{h}}$ & 1.09 & $6.54^{\mathrm{h}}$ & $59.11^{\mathrm{c}}$ & $3.56^{\mathrm{i}}$ \\
\hline Mean & & $9.88^{\mathrm{c}}$ & $17.48^{\mathrm{c}}$ & $2.74^{\mathrm{c}}$ & $1.08^{\mathrm{a}}$ & $6.58^{\mathrm{c}}$ & $61.25^{\mathrm{a}}$ & $5.52^{\mathrm{c}}$ \\
\hline \multirow{3}{*}{$\begin{array}{l}75 \% \text { Burghul }+ \\
25 \% \text { faba bean }\end{array}$} & Cow milk & $10.38^{\mathrm{e}}$ & $22.27^{\mathrm{e}}$ & $4.96^{\mathrm{b}}$ & 1.01 & $7.13^{f}$ & $54.25^{\mathrm{f}}$ & $6.62^{\mathrm{d}}$ \\
\hline & $\begin{array}{l}\text { Skimmed } \\
\text { milk }\end{array}$ & $10.72^{c}$ & $23.82^{\mathrm{d}}$ & $2.04^{\mathrm{g}}$ & 0.93 & $7.57^{\mathrm{d}}$ & $54.91^{\mathrm{e}}$ & $6.72^{\mathrm{c}}$ \\
\hline & Laban Zeer & $10.11^{\mathrm{f}}$ & $21.28^{f}$ & $2.27^{f}$ & 0.99 & $7.47^{\mathrm{e}}$ & $54.25^{\mathrm{f}}$ & $3.75^{\mathrm{h}}$ \\
\hline Mean & & $10.41^{\mathrm{b}}$ & $22.45^{\mathrm{b}}$ & $3.09^{\mathrm{b}}$ & $0.98^{\mathrm{b}}$ & $7.39^{\mathrm{b}}$ & $55.68^{\mathrm{b}}$ & $5.70^{\mathrm{b}}$ \\
\hline \multirow{3}{*}{$\begin{array}{l}50 \% \text { Burghul }+ \\
50 \% \text { faba bean }\end{array}$} & Cow milk & $10.93^{b}$ & $26.52^{\mathrm{b}}$ & $5.70^{\mathrm{a}}$ & 0.90 & $8.04^{\mathrm{c}}$ & $52.50^{\mathrm{g}}$ & $6.78^{b}$ \\
\hline & $\begin{array}{l}\text { Skimmed } \\
\text { milk }\end{array}$ & $11.18^{\mathrm{a}}$ & $28.41^{\mathrm{a}}$ & $2.55^{\mathrm{e}}$ & 0.82 & $8.42^{\mathrm{a}}$ & $48.60^{\mathrm{h}}$ & $6.86^{\mathrm{a}}$ \\
\hline & Laban Zeer & $10.56^{\mathrm{d}}$ & $24.92^{\mathrm{c}}$ & $2.95^{\mathrm{d}}$ & 0.87 & $8.19^{b}$ & $47.90^{\mathrm{i}}$ & $3.91^{\mathrm{g}}$ \\
\hline Mean & & $10.89^{\mathrm{a}}$ & $26.62^{\mathrm{a}}$ & $3.73^{\mathrm{a}}$ & $0.86^{\mathrm{c}}$ & $8.22^{\mathrm{a}}$ & $49.67^{\mathrm{c}}$ & $5.85^{\mathrm{a}}$ \\
\hline \multirow{3}{*}{$\begin{array}{l}\text { Averages } \\
\text { milk type }\end{array}$} & Cow milk & $10.39^{b}$ & $20.86^{\mathrm{c}}$ & $5.09^{\mathrm{a}}$ & $1.01^{\mathrm{a}}$ & $7.20^{c}$ & $58.25^{\mathrm{a}}$ & $6.62^{b}$ \\
\hline & $\begin{array}{l}\text { Skimmed } \\
\text { milk }\end{array}$ & $10.66^{\mathrm{a}}$ & $22.19^{\mathrm{b}}$ & $2.11^{\mathrm{c}}$ & $0.93^{\mathrm{c}}$ & $7.40^{\mathrm{b}}$ & $55.22^{\mathrm{b}}$ & $6.71^{\mathrm{a}}$ \\
\hline & Laban Zeer & $10.13^{\mathrm{c}}$ & $23.50^{\mathrm{a}}$ & $2.38^{\mathrm{b}}$ & $0.98^{\mathrm{b}}$ & $7.59^{\mathrm{a}}$ & $52.80^{\mathrm{c}}$ & $3.54^{\mathrm{c}}$ \\
\hline Overall mean & & 10.39 & 22.18 & 3.19 & 0.97 & 7.40 & 55.42 & 5.62 \\
\hline \multirow[t]{3}{*}{$\mathrm{F}$ value } & A & $* *$ & $* *$ & $* *$ & $* *$ & $* *$ & $* *$ & $* *$ \\
\hline & B & $* *$ & $* *$ & $* *$ & $* *$ & $* *$ & $* *$ & $* *$ \\
\hline & $\mathrm{AB}$ & $* *$ & $* *$ & $* *$ & Ns & ** & $* *$ & $*$ \\
\hline \multirow[t]{3}{*}{ LSD at $5 \%$} & A & 0.02 & 0.08 & 0.02 & 0.004 & 0.01 & 0.09 & 0.02 \\
\hline & B & 0.03 & 0.05 & 0.04 & 0.003 & 0.02 & 0.06 & 0.02 \\
\hline & $\mathrm{AB}$ & 0.03 & 0.07 & 0.05 & - & 0.03 & 0.08 & 0.03 \\
\hline
\end{tabular}

Carbo. $* \%=$ carbohydrates $\%$. Notes: Values in the same row with different superscripts are statistically significant from each other $(p<$ 0.05).

phenylalanine (4.26\%), valine (4.19\%), histidine $(2.41 \%)$ and tyrosine $(3.49 \%)$, as well as the lowest value of methionine $(0.63 \%)$ than burghul. It is containing the lower values of threonine $(2.68 \%)$, isoleucine $(2.13 \%)$, leucine $(4.70 \%)$, lysine $(2.48 \%)$, phenylalanine $(2.42 \%)$, valine $(2.55 \%)$, histidine $(1.28 \%)$ and tyrosine $(1.62 \%)$ as well as the highest value of methionine $(0.88 \%)$. These findings agree with those obtained by El.Fiel et al., (2014); Abd El-Ghani et al. (2014) and Bahgaat \& Abd El.Ghani (2017). They clarified that the cheap source of energy is cereals. They added that faba bean seeds are supply a high percentage of calorie and protein especially to large segment of human population, particularly in developing countries. Concerning type of milk, the results in Tables $(3 \& 4)$ referred that there were significant differences in essential amino acids composition of Saidy Kishk samples prepared from different types of milk i.e., full cow milk, skimmed milk, and Laban Zeer. The highest values of threonine $(3.43 \%)$, isoleucine $(5.20 \%)$, leucine $(9.58 \%)$, lysine (4.66\%), methionine (2.18\%), phenylalanine $(4.86 \%)$, valine $(4.49 \%)$, histidine $(2.91 \%)$ and the lowest value of tyrosine $(1.42 \%)$ were found in Saidy Kishk manufactured from skimmed milk. Conversely with respect to Saidy Kishk manufactured from Laban Zeer, which contained the lowest values. Similar findings were reported by Abd El-Ghani et al., (2014) and Bahgaat \& Abd El.Ghani (2017). They reported that the proteins present in milk, especially skimmed milk have high value of biological and good amino acids profiles. From the same Tables, $3 \& 4$ clarified that a significant interaction was recorded between cereal type \& percent and milk type used in processing Saidy Kish regarding essential amino acids composition, i.e., threonine, isoleucine, leucine, lysine, methionine, 
Table 3: Effect of replacing bulgur by percent of broken faba bean seeds on essential amino acids of Saidy kishk manufactured from different types of milk.

\begin{tabular}{|c|c|c|c|c|c|c|}
\hline \multirow{2}{*}{$\begin{array}{l}\text { Type and percent of } \\
\text { cereal (A) }\end{array}$} & \multirow[t]{2}{*}{ Type of milk (B) } & \multicolumn{5}{|c|}{ Essential amino acids g/100 g protein of Saidy kishk } \\
\hline & & Threonine & Isoleucine & Leucine & Lysine & Methionine \\
\hline \multirow[t]{3}{*}{ Burghul $100 \%$} & Cow milk & $2.66^{\mathrm{f}}$ & 4.38 & $8.24^{\mathrm{h}}$ & $3.09^{\mathrm{h}}$ & $2.06^{\mathrm{d}}$ \\
\hline & Skimmed milk & $3.17^{\mathrm{d}}$ & 4.74 & $8.54^{\mathrm{f}}$ & $3.21^{\mathrm{g}}$ & $2.26^{\mathrm{a}}$ \\
\hline & Laban Zeer & $2.24^{\mathrm{h}}$ & 3.54 & $7.65^{\mathrm{i}}$ & $2.71^{\mathrm{i}}$ & $1.46^{\mathrm{g}}$ \\
\hline Mean & & $2.69^{c}$ & $4.22^{\mathrm{c}}$ & $8.14^{\mathrm{c}}$ & $3.00^{\mathrm{c}}$ & $1.93^{\mathrm{a}}$ \\
\hline \multirow{3}{*}{$\begin{array}{l}75 \% \text { Burghul } \\
25 \% \text { faba bean }\end{array}$} & Cow milk & $2.91^{\mathrm{e}}$ & 4.77 & $8.98^{\mathrm{e}}$ & $4.13^{\mathrm{e}}$ & $1.98^{\mathrm{e}}$ \\
\hline & Skimmed milk & $3.37^{\mathrm{b}}$ & 5.07 & $9.29^{\mathrm{d}}$ & $4.31^{\mathrm{d}}$ & $2.19^{\mathrm{b}}$ \\
\hline & Laban Zeer & $2.43^{\mathrm{g}}$ & 3.89 & $8.37^{\mathrm{g}}$ & $3.81^{\mathrm{f}}$ & $1.39^{\mathrm{h}}$ \\
\hline Mean & & $2.90^{\mathrm{b}}$ & $4.58^{\mathrm{b}}$ & $8.88^{\mathrm{b}}$ & $4.08^{\mathrm{b}}$ & $1.85^{\mathrm{b}}$ \\
\hline \multirow{3}{*}{$\begin{array}{l}50 \% \text { Burghul } \\
50 \% \text { faba bean }\end{array}$} & Cow milk & $3.31^{\mathrm{c}}$ & 5.42 & $10.54^{b}$ & $6.29^{b}$ & $1.91^{\mathrm{f}}$ \\
\hline & Skimmed milk & $3.75^{\mathrm{a}}$ & 5.77 & $10.91^{\mathrm{a}}$ & $6.47^{\mathrm{a}}$ & $2.11^{\mathrm{c}}$ \\
\hline & Laban Zeer & $2.65^{f}$ & 4.59 & $9.95^{\mathrm{c}}$ & $5.92^{\mathrm{c}}$ & $1.32^{\mathrm{i}}$ \\
\hline Mean & & $3.24^{\mathrm{a}}$ & $5.26^{\mathrm{a}}$ & $10.47^{\mathrm{a}}$ & $6.23^{\mathrm{a}}$ & $1.78^{\mathrm{c}}$ \\
\hline \multirow{3}{*}{$\begin{array}{l}\text { Averages of milk } \\
\text { type }\end{array}$} & Cow milk & $2.96^{\mathrm{b}}$ & $4.86^{\mathrm{b}}$ & $9.25^{\mathrm{b}}$ & $4.51^{\mathrm{b}}$ & $1.98^{\mathrm{b}}$ \\
\hline & Skimmed milk & $3.43^{\mathrm{a}}$ & $5.20^{\mathrm{a}}$ & $9.58^{\mathrm{a}}$ & $4.66^{\mathrm{a}}$ & $2.18^{\mathrm{a}}$ \\
\hline & Laban Zeer & $2.44^{\mathrm{c}}$ & $4.01^{\mathrm{c}}$ & $8.66^{\mathrm{c}}$ & $4.15^{\mathrm{c}}$ & $1.39^{\mathrm{c}}$ \\
\hline Overall mean & & 2.94 & 4.69 & 9.16 & 4.44 & 1.85 \\
\hline \multirow[t]{3}{*}{ F value } & A & $* *$ & $* *$ & $* *$ & $* *$ & $* *$ \\
\hline & $\mathrm{B}$ & $* *$ & $* *$ & $* *$ & $* *$ & $* *$ \\
\hline & $\mathrm{AB}$ & $* *$ & Ns & $* *$ & $* *$ & $\mathrm{Ns}$ \\
\hline \multirow[t]{3}{*}{ LSD at $5 \%$} & A & 0.02 & 0.03 & 0.02 & 0.02 & 0.01 \\
\hline & $\mathrm{B}$ & 0.02 & 0.02 & 0.02 & 0.02 & 0.01 \\
\hline & $\mathrm{AB}$ & 0.03 & - & 0.03 & 0.03 & - \\
\hline
\end{tabular}

Notes: Values in the same row with different superscripts are statistically significant from each other $(p<0.05)$.

Table 4: Effect of replacing bulgur by percent of broken faba bean seeds on essential amino acids of Saidy kishk manufactured from different types of milk.

\begin{tabular}{|c|c|c|c|c|c|c|}
\hline \multirow{2}{*}{$\begin{array}{l}\text { Type and percent o } \\
\text { cereal (A) }\end{array}$} & \multirow{2}{*}{ Type of milk(B) } & \multicolumn{5}{|c|}{ Essential amino acids $\mathrm{g} / 100 \mathrm{~g}$ protein of Saidy kishk } \\
\hline & & phenylalanine & Valine & Histidine & Tyrosine & Tryptophan \\
\hline \multirow[t]{3}{*}{ Burghul 100\% } & Cow milk & $4.19^{\mathrm{g}}$ & $3.92^{\mathrm{f}}$ & $2.24^{\mathrm{f}}$ & $1.92^{\mathrm{d}}$ & ND \\
\hline & Skimmed milk & $4.44^{\mathrm{e}}$ & $4.11^{\mathrm{e}}$ & $2.72^{\mathrm{c}}$ & $1.09^{\mathrm{i}}$ & ND \\
\hline & Laban Zeer & $3.95^{\mathrm{i}}$ & $2.84^{\mathrm{i}}$ & $1.63^{\mathrm{i}}$ & $1.62^{\mathrm{g}}$ & ND \\
\hline Mean & & $4.19^{c}$ & $3.63^{\mathrm{c}}$ & $2.20^{\mathrm{c}}$ & $1.54^{\mathrm{c}}$ & - \\
\hline \multirow{3}{*}{$\begin{array}{l}75 \% \text { Burghul } \\
25 \% \text { faba bean }\end{array}$} & Cow milk & $4.57^{\mathrm{d}}$ & $4.25^{\mathrm{d}}$ & $2.42^{\mathrm{e}}$ & $2.17^{\mathrm{e}}$ & ND \\
\hline & Skimmed milk & $4.83^{c}$ & $4.48^{c}$ & $2.89^{b}$ & $1.42^{\mathrm{h}}$ & ND \\
\hline & Laban Zeer & $4.28^{f}$ & $3.03^{\mathrm{h}}$ & $1.85^{\mathrm{h}}$ & $1.88^{\mathrm{e}}$ & ND \\
\hline Mean & & $4.56^{\mathrm{b}}$ & $3.92^{\mathrm{b}}$ & $2.39^{\mathrm{b}}$ & $1.82^{\mathrm{b}}$ & - \\
\hline \multirow{3}{*}{$\begin{array}{l}50 \% \text { Burghul } \\
50 \% \text { faba bean }\end{array}$} & Cow milk & $4.91^{\mathrm{b}}$ & $4.60^{b}$ & $2.57^{d}$ & $2.44^{\mathrm{a}}$ & ND \\
\hline & Skimmed milk & $5.33^{\mathrm{a}}$ & $4.88^{\mathrm{a}}$ & $3.11^{\mathrm{a}}$ & $1.75^{\mathrm{g}}$ & ND \\
\hline & Laban Zeer & $4.59^{d}$ & $3.38^{\mathrm{g}}$ & $2.03^{\mathrm{g}}$ & $2.14^{\mathrm{c}}$ & ND \\
\hline Mean & & $4.94^{\mathrm{a}}$ & $4.29^{\mathrm{a}}$ & $2.57^{\mathrm{a}}$ & $2.11^{\mathrm{a}}$ & - \\
\hline \multirow{3}{*}{$\begin{array}{l}\text { Averages of milk } \\
\text { type }\end{array}$} & Cow milk & $4.55^{\mathrm{b}}$ & $4.26^{\mathrm{b}}$ & $2.41^{\mathrm{b}}$ & $2.18^{\mathrm{a}}$ & ND \\
\hline & Skimmed milk & $4.86^{\mathrm{a}}$ & $4.49^{\mathrm{a}}$ & $2.91^{\mathrm{a}}$ & $1.42^{\mathrm{c}}$ & ND \\
\hline & Laban Zeer & $4.28^{c}$ & $3.09^{c}$ & $1.84^{\mathrm{c}}$ & $1.88^{\mathrm{b}}$ & ND \\
\hline Overall mean & & 4.56 & 3.94 & 2.38 & 1.82 & - \\
\hline \multirow[t]{3}{*}{ F value } & A & $* *$ & $* *$ & $* *$ & $* *$ & - \\
\hline & $\mathrm{B}$ & $* *$ & $* *$ & $* *$ & $* *$ & - \\
\hline & $\mathrm{AB}$ & $* *$ & $* *$ & $* *$ & $* *$ & - \\
\hline \multirow[t]{3}{*}{ LSD at $5 \%$} & A & 0.02 & 0.02 & 0.02 & 0.02 & - \\
\hline & B & 0.02 & 0.03 & 0.02 & 0.01 & - \\
\hline & $\mathrm{AB}$ & 0.03 & 0.04 & 0.03 & 0.02 & - \\
\hline
\end{tabular}

Notes: Values in the same row with different superscripts are statistically significant from each other $(\mathrm{p}<0.05)$. ND= Not detected. 
phenylalanine, valine, histidine and tyrosine except methionine and tryptophan. Saidy Kishk samples manufactured from 50\% B + $50 \% \mathrm{Fb}$ with skimmed milk had the highest values of threonine $(3.75 \%)$, leucine $(10.91 \%)$, lysine $(6.47 \%)$, phenylalanine $(5.33 \%)$, valine $(4.88 \%)$ and histidine $(3.11 \%)$. These results are in the same line with that obtained by Abd El-Ghani et al., (2014) and Bahgaat \& Abd El-Ghani (2017). They noted that kishk has considerable dietary potential as source of amino acids. They added that there is lack information about its amino acids which are important as bioactive compounds.

3.1.3. Mineral composition of Saidy Kishk: Results in Table, 5 summarized mineral composition, i.e., $\mathrm{Ca}, \mathrm{Mg}, \mathrm{K}, \mathrm{Na}, \mathrm{P}$ and $\mathrm{Fe}$ of Saidy Kishk produced from replacing bulgur by different percent's of broken faba bean seeds. It was evident that formula (type and percent) of cereal had a significant effect on minerals composition of Saidy Kishk samples. Saidy Kishk formula manufactured from $50 \%$ $\mathrm{B}+50 \% \mathrm{Fb}$ contained the highest values of $\mathrm{Ca}$ (299.78 mg),Mg (161.44 mg), K (1012.78mg) and $\mathrm{Na}(4129.44 \mathrm{mg} / 100 \mathrm{~g} \mathrm{DWB})$ as well as the highest value of $\mathrm{Fe}$ element (6.67 ppm). Conversely, it scored the lowest value of $\mathrm{P}$ element (387.78mg/100 g DWB). However, the lowest values of $\mathrm{Ca}(231.78 \mathrm{mg}), \mathrm{Mg}$ (105.89 mg), K (662.22 mg) and $\mathrm{Na}(4116.67$ $\mathrm{mg} / 100 \mathrm{~g}$ DWB) were recorded for Saidy Kishk manufactured from $100 \% \mathrm{~B}$ conversely, it contains the highest value of $\mathrm{P}$ element (437.33 mg/100 g DWB). Such differences might be due to the variation of ash content of burghul and faba bean. The results are in good line with those reported by Abd El-Ghani et al., (2014). They added that iron deficiency is the most common nutritional deficiency in the world, and one of the few nutritional deficiency conditions that remains common in the developed world. In addition, in the same Table, the data clarified that type of milk i.e., full cow milk, skimmed milk and Laban Zeer had a significant effect on mineral composition ( $\mathrm{Ca}, \mathrm{Mg}, \mathrm{K}, \mathrm{Na}, \mathrm{P}$ and $\mathrm{Fe}$ ) of Saidy Kishk samples. Saidy Kishk samples prepared from skimmed milk contained the highest values of $\mathrm{Ca}$ (288.56mg), $\mathrm{Mg}$ (147.00mg), K (927.67mg), Na (4131.89mg), $\mathrm{P}(425.00 / 100 \mathrm{~g} \mathrm{DWB})$ and $\mathrm{Fe}$ (6.66 ppm). On the other hand, the lowest values of $\mathrm{Ca}$ (244.00mg), Mg (123.22mg), K (796.00mg), $\mathrm{Na}(4115.11 \mathrm{mg}), \mathrm{P}(403.11 / 100 \mathrm{~g}$ DWB) and $\mathrm{Fe}(5.82 \mathrm{ppm})$ were found in Saidy Kishk samples prepared from full cow milk. This might be attributed to that ash content of skimmed milk was the highest. Such findings are in harmony with those recorded by Erkaya \& Sengül (2011) and Atamian et al., (2014). It is noteworthy here to mention that Saidy Kishk samples prepared from skimmed milk are considered rich source for the minerals. Significant interactions between cereal formula (type and percent of cereal) and milk type used in the manufacture with regard to mineral composition $(\mathrm{Ca}, \mathrm{Mg}, \mathrm{K}, \mathrm{Na}, \mathrm{P}$ and $\mathrm{Fe})$ of Saidy Kishk samples except $\mathrm{Na}$ element were shown in Table, 5. Saidy Kishk samples manufactured from $50 \% \mathrm{~B}+50 \% \mathrm{Fb}$ with skimmed milk had the highest values of $\mathrm{Ca}$ (319.67 mg), Mg (172.00 mg), K (1117.67mg/100g DWB) and Fe (7.19 ppm); these findings are in rather close accordance with that reported by Erkaya and Sengül (2011).

3.2. Microbiological quality of Saidy Kishk: As can be seen in Table, 6 microbial loads of Saidy Kishk as affected by cereal formula (type and percent of cereal) and milk type used in the manufacture regarding total bacterial count, Lactic acid bacteria count, Coliform bacteria count, molds \&yeast count in experimental samples. Formula of type and percent of cereal had a significant effect on total bacterial count and Lactic acid bacteria count of Saidy Kishk samples. Saidy Kishk samples manufactured from $50 \% \mathrm{~B}+50 \% \mathrm{Fb}$ contained the highest values of total bacterial count and Lactic acid bacteria count ( 8.70 and $7.10 \log \mathrm{CFU} / \mathrm{g}$ ), while, the lowest values (6.30 and $4.94 \log$ CFU/g) were recorded for samples of Saidy Kishk samples manufactured from $100 \% \mathrm{~B}$, respectively. This may be due to hydrolysis and percent of protein to peptides and free amino was higher in broken faba bean seeds than wheat and by 
Table 5: Effect of replacing bulgur by percent of broken faba bean seeds on mineral contents of Saidy kishk manufactured from different types of milk.

\begin{tabular}{|c|c|c|c|c|c|c|c|}
\hline \multirow{2}{*}{$\begin{array}{l}\text { Type and } \\
\text { percent } \\
\text { of cereal } \\
\text { (A) }\end{array}$} & \multirow[t]{2}{*}{ Type of milk (B) } & \multicolumn{6}{|c|}{ Minerals contents of Saidy kishk } \\
\hline & & $\mathrm{Ca}(\mathrm{mg} / 100 \mathrm{~g})$ & $\begin{array}{c}\mathrm{Mg} \\
(\mathrm{mg} / 100 \mathrm{~g})\end{array}$ & $\mathrm{K}(\mathrm{mg} / 100 \mathrm{~g})$ & $\mathrm{Na}(\mathrm{mg} / 100 \mathrm{~g})$ & $\mathrm{P}(\mathrm{mg} / 100 \mathrm{~g})$ & $\begin{array}{c}\mathrm{Fe} \\
(\mathrm{ppm})\end{array}$ \\
\hline \multirow{3}{*}{$\begin{array}{l}\text { Burghul } \\
100 \%\end{array}$} & Cow milk & $206.67^{\mathrm{i}}$ & $95.00^{\mathrm{h}}$ & $616.67^{\mathrm{i}}$ & 4109.00 & $424.33^{\mathrm{d}}$ & $5.32^{\mathrm{i}}$ \\
\hline & Skimmed milk & $254.00^{f}$ & $117.00^{\mathrm{f}}$ & $722.67^{g}$ & 4125.00 & $452.33^{\mathrm{a}}$ & $6.12^{\mathrm{e}}$ \\
\hline & Laban Zeer & $234.67^{\mathrm{h}}$ & $105.67^{\mathrm{g}}$ & $647.33^{\mathrm{h}}$ & 4116.00 & $435.33^{b}$ & $5.52^{\mathrm{h}}$ \\
\hline Mean & & $231.78^{c}$ & $105.89^{c}$ & $662.22^{\mathrm{c}}$ & $4116.67^{\mathrm{c}}$ & $437.33^{\mathrm{a}}$ & $5.65^{\mathrm{c}}$ \\
\hline \multirow{3}{*}{$\begin{array}{l}75 \% \text { Bur } \\
\text { ghul + } \\
25 \% \text { faba } \\
\text { bean }\end{array}$} & Cow milk & $243.67^{g}$ & $123.33^{\mathrm{e}}$ & $836.67^{\mathrm{e}}$ & 4115.67 & $402.67^{f}$ & $5.87^{g}$ \\
\hline & Skimmed milk & $292.00^{c}$ & $152.00^{\mathrm{c}}$ & $942.67^{c}$ & 4132.00 & $429.67^{c}$ & $6.68^{b}$ \\
\hline & Laban Zeer & $272.33^{\mathrm{e}}$ & $132.00^{\mathrm{d}}$ & $810.33^{\mathrm{f}}$ & 4123.33 & $415.33^{\mathrm{e}}$ & $5.98^{\mathrm{f}}$ \\
\hline Mean & & $269.33^{b}$ & $135.78^{b}$ & $863.22^{b}$ & $4123.67^{b}$ & $415.89^{b}$ & $6.17^{b}$ \\
\hline \multirow{3}{*}{$\begin{array}{l}50 \% \text { Bur } \\
\text { ghul + } \\
50 \% \text { faba } \\
\text { bean }\end{array}$} & Cow milk & $281.67^{b}$ & $151.33^{\mathrm{c}}$ & $934.67^{\mathrm{d}}$ & 4120.67 & $382.33^{\mathrm{i}}$ & $6.28^{\mathrm{d}}$ \\
\hline & Skimmed milk & $319.67^{\mathrm{a}}$ & $172.00^{\mathrm{a}}$ & $1117.67^{\mathrm{a}}$ & 4138.67 & $393.00^{\mathrm{g}}$ & $7.19^{\mathrm{a}}$ \\
\hline & Laban Zeer & $298.00^{b}$ & $161.00^{\mathrm{b}}$ & $986.00^{\mathrm{b}}$ & 4129.00 & $388.00^{\mathrm{h}}$ & $6.55^{\mathrm{c}}$ \\
\hline Mean & & $299.78^{\mathrm{a}}$ & $161.44^{\mathrm{a}}$ & $1012.78^{\mathrm{a}}$ & $4129.44^{\mathrm{a}}$ & $387.78^{c}$ & $6.67^{\mathrm{a}}$ \\
\hline \multirow{3}{*}{$\begin{array}{l}\text { Average } \\
\text { s of milk } \\
\text { type }\end{array}$} & Cow milk & $244.00^{c}$ & $123.22^{\mathrm{c}}$ & $796.00^{\mathrm{c}}$ & $4115.11^{\mathrm{c}}$ & $403.11^{\mathrm{c}}$ & $5.82^{\mathrm{c}}$ \\
\hline & Skimmed milk & $288.56^{\mathrm{a}}$ & $147.00^{\mathrm{a}}$ & $927.67^{\mathrm{a}}$ & $4122.78^{b}$ & $425.00^{\mathrm{a}}$ & $6.66^{\mathrm{a}}$ \\
\hline & Laban Zeer & $268.33^{b}$ & $132.89^{b}$ & $814.56^{\mathrm{b}}$ & $4131.89^{\mathrm{a}}$ & $412.89^{b}$ & $6.01^{\mathrm{b}}$ \\
\hline \multicolumn{2}{|c|}{ Overall mean } & 266.96 & 134.37 & 846.07 & 4123.26 & 413.67 & 6.17 \\
\hline \multirow[t]{3}{*}{ F value } & A & $* *$ & $* *$ & $* *$ & $* *$ & $* *$ & $* *$ \\
\hline & $\mathrm{B}$ & $* *$ & $* *$ & $* *$ & $* *$ & $* *$ & $* *$ \\
\hline & $\mathrm{AB}$ & $* *$ & *** & *** & Ns & ** & $* *$ \\
\hline \multirow{3}{*}{$\begin{array}{l}\text { LSD at } \\
5 \%\end{array}$} & A & 1.92 & 1.18 & 3.61 & 1.33 & 2.05 & 0.02 \\
\hline & B & 2.36 & 1.14 & 1.76 & 1.50 & 1.57 & 0.01 \\
\hline & $\mathrm{AB}$ & 3.40 & 1.64 & 2.53 & - & 2.26 & 0.02 \\
\hline
\end{tabular}

Notes: Values in the same row with different superscripts are statistically significant from each other $(p<0.05)$.

Table 6: Effect of replacing bulgur with different levels of broken faba bean seeds on microbiological quality of Saidy kishk manufactured from different types of milk.

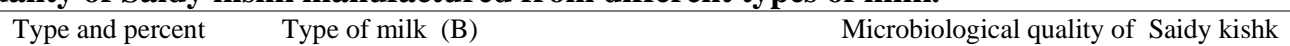
of cereal (A)

\begin{tabular}{|c|c|c|c|c|c|}
\hline & & $\begin{array}{l}\text { Total bacterial count } \\
\quad(\log \mathrm{CFU} / \mathrm{g})\end{array}$ & $\begin{array}{l}\text { Lactic acid bacteria } \\
\text { count }(\log \mathrm{CFU} / \mathrm{g})\end{array}$ & $\begin{array}{c}\text { Coliform } \\
\text { bacteria count } \\
(\log \mathrm{CFU} / \mathrm{g})\end{array}$ & $\begin{array}{l}\text { Molds \&yeast count } \\
\quad(\log \mathrm{CFU} / \mathrm{g})\end{array}$ \\
\hline \multirow[t]{3}{*}{ Burghul 100\% } & Cow milk & $6.91^{\mathrm{g}}$ & $5.44^{\mathrm{g}}$ & $<10$ & $<10$ \\
\hline & Skimmed milk & $4.65^{\mathrm{i}}$ & $3.26^{\mathrm{i}}$ & $<10$ & $<10$ \\
\hline & Laban Zeer & $7.34^{\mathrm{f}}$ & $6.12^{\mathrm{e}}$ & $<10$ & $<10$ \\
\hline \multicolumn{2}{|c|}{ Mean } & $6.30^{c}$ & $4.94^{\mathrm{c}}$ & - & - \\
\hline \multirow{3}{*}{$\begin{array}{l}75 \% \text { Burghul }+ \\
25 \% \text { faba bean }\end{array}$} & Cow milk & $7.54^{\mathrm{d}}$ & $6.28^{\mathrm{d}}$ & $<10$ & $<10$ \\
\hline & Skimmed milk & $5.18^{\mathrm{h}}$ & $4.47^{\mathrm{h}}$ & $<10$ & $<10$ \\
\hline & Laban Zeer & $8.55^{\mathrm{c}}$ & $7.46^{\mathrm{b}}$ & $<10$ & $<10$ \\
\hline \multicolumn{2}{|c|}{ Mean } & $7.09^{b}$ & $6.07^{b}$ & - & - \\
\hline \multirow{3}{*}{$\begin{array}{l}50 \% \text { Burghul }+ \\
50 \% \text { faba bean }\end{array}$} & Cow milk & $8.92^{\mathrm{b}}$ & $7.33^{\mathrm{c}}$ & $<10$ & $<10$ \\
\hline & Skimmed milk & $7.40^{\mathrm{e}}$ & $5.88^{f}$ & $<10$ & $<10$ \\
\hline & Laban Zeer & $9.77^{\mathrm{a}}$ & $8.09^{\mathrm{a}}$ & $<10$ & $<10$ \\
\hline \multicolumn{2}{|c|}{ Mean } & $8.70^{\mathrm{a}}$ & $7.10^{\mathrm{a}}$ & - & - \\
\hline \multirow{3}{*}{$\begin{array}{l}\text { Averages of milk } \\
\text { type }\end{array}$} & Cow milk & $7.79^{\mathrm{b}}$ & $6.35^{\mathrm{b}}$ & $<10$ & $<10$ \\
\hline & Skimmed milk & $5.74^{\mathrm{c}}$ & $4.54^{\mathrm{c}}$ & $<10$ & $<10$ \\
\hline & Laban Zeer & $8.55^{\mathrm{a}}$ & $7.22^{\mathrm{a}}$ & $<10$ & $<10$ \\
\hline \multicolumn{2}{|c|}{ Overall mean } & 7.36 & 6.04 & - & - \\
\hline \multirow[t]{3}{*}{ F value } & A & $* *$ & $* *$ & Ns & Ns \\
\hline & $\mathrm{B}$ & $* *$ & $* *$ & Ns & Ns \\
\hline & $\mathrm{AB}$ & $* *$ & $* *$ & Ns & Ns \\
\hline \multirow[t]{3}{*}{ LSD at $5 \%$} & A & 0.04 & 0.03 & - & - \\
\hline & $\mathrm{B}$ & 0.02 & 0.02 & - & - \\
\hline & $\mathrm{AB}$ & 0.03 & 0.03 & - & - \\
\hline
\end{tabular}

Notes: Values in the same row with different superscripts are statistically significant from each other $(p<0.05)$ 
Table 7: Effect of replacing bulgur with different levels of broken faba bean seeds on sensory quality of Saidy kishk manufactured from different types of milk.

\begin{tabular}{|c|c|c|c|c|c|c|}
\hline \multirow{2}{*}{$\begin{array}{l}\text { Type and } \\
\text { percent of } \\
\text { cereal (A) }\end{array}$} & \multirow{2}{*}{$\begin{array}{l}\text { Type of milk } \\
\text { (B) }\end{array}$} & \multicolumn{5}{|c|}{ Sensory quality of Saidy kishk } \\
\hline & & $\begin{array}{c}\text { Taste } \\
\text { (25 points })\end{array}$ & $\begin{array}{l}\text { Appearance } \\
\text { ( } 25 \text { points ) }\end{array}$ & $\begin{array}{c}\text { Flavor } \\
\text { (25 points })\end{array}$ & $\begin{array}{c}\text { Texture } \\
(25 \text { points })\end{array}$ & $\begin{array}{c}\text { Overall } \\
\text { acceptability (100 } \\
\text { points ) }\end{array}$ \\
\hline \multirow{3}{*}{$\begin{array}{l}\text { Burghul } \\
100 \%\end{array}$} & Cow milk & $20.18^{\mathrm{g}}$ & $19.74^{\mathrm{i}}$ & $19.89^{h}$ & $19.70^{\mathrm{h}}$ & $79.51^{\mathrm{i}}$ \\
\hline & Skim milk & $21.52^{\mathrm{e}}$ & $20.22^{\mathrm{g}}$ & $22.12^{\mathrm{c}}$ & $19.17^{\mathrm{i}}$ & $83.03^{\mathrm{f}}$ \\
\hline & Zeer milk & $18.90^{\mathrm{h}}$ & $21.22^{\mathrm{c}}$ & $21.43^{\mathrm{e}}$ & $19.86^{\mathrm{g}}$ & $81.41^{\mathrm{h}}$ \\
\hline \multicolumn{2}{|c|}{ Mean } & $20.20^{c}$ & $20.39^{c}$ & $21.15^{\mathrm{c}}$ & $19.57^{\mathrm{c}}$ & $81.32^{\mathrm{c}}$ \\
\hline \multirow{3}{*}{$\begin{array}{l}75 \% \text { Burghul } \\
+25 \% \text { faba } \\
\text { bean }\end{array}$} & Cow milk & $21.33^{f}$ & $20.19^{h}$ & $20.16^{\mathrm{g}}$ & $20.81^{\mathrm{f}}$ & $82.50^{\mathrm{g}}$ \\
\hline & Skim milk & $22.43^{\mathrm{c}}$ & $20.75^{\mathrm{e}}$ & $22.59^{b}$ & $21.56^{\mathrm{c}}$ & $87.33^{c}$ \\
\hline & Zeer milk & $21.82^{d}$ & $21.07^{\mathrm{d}}$ & $21.92^{\mathrm{d}}$ & $21.17^{\mathrm{e}}$ & $85.98^{\mathrm{d}}$ \\
\hline \multicolumn{2}{|c|}{ Mean } & $21.86^{b}$ & $20.67^{b}$ & $21.56^{b}$ & $21.18^{b}$ & $85.27^{b}$ \\
\hline \multirow{3}{*}{$\begin{array}{c}50 \% \text { Burghul } \\
+50 \% \text { faba } \\
\text { bean }\end{array}$} & Cow milk & $21.87^{\mathrm{d}}$ & $20.50^{f}$ & $20.86^{f}$ & $21.43^{\mathrm{d}}$ & $84.67^{\mathrm{e}}$ \\
\hline & Skim milk & $23.35^{\mathrm{a}}$ & $21.42^{b}$ & $22.91^{\mathrm{a}}$ & $22.34^{\mathrm{a}}$ & $90.03^{\mathrm{a}}$ \\
\hline & Zeer milk & $22.62^{b}$ & $21.74^{\mathrm{a}}$ & $22.56^{b}$ & $21.77^{\mathrm{b}}$ & $88.70^{b}$ \\
\hline \multicolumn{2}{|c|}{ Mean } & $22.61^{\mathrm{a}}$ & $21.22^{\mathrm{a}}$ & $22.11^{\mathrm{a}}$ & $21.85^{\mathrm{a}}$ & $87.80^{\mathrm{a}}$ \\
\hline \multirow{3}{*}{$\begin{array}{l}\text { Averages of } \\
\text { milk type }\end{array}$} & Cow milk & $21.13^{b}$ & $20.14^{\mathrm{c}}$ & $20.30^{b}$ & $20.65^{c}$ & $82.23^{\mathrm{c}}$ \\
\hline & Skim milk & $22.43^{\mathrm{a}}$ & $20.80^{b}$ & $22.54^{\mathrm{a}}$ & $21.02^{\mathrm{a}}$ & $86.79^{a}$ \\
\hline & Zeer milk & $21.12^{b}$ & $21.34^{\mathrm{a}}$ & $21.97^{b}$ & $20.93^{b}$ & $85.36^{\mathrm{b}}$ \\
\hline \multicolumn{2}{|c|}{ Overall mean } & 21.56 & 20.76 & 21.61 & 20.87 & 84.79 \\
\hline \multirow[t]{3}{*}{ F value } & A & $* *$ & $* *$ & $* *$ & $* *$ & $* *$ \\
\hline & $\mathrm{B}$ & $* *$ & $* *$ & $* *$ & $* *$ & $* *$ \\
\hline & $\mathrm{AB}$ & $* *$ & $* *$ & $* *$ & $* *$ & $* *$ \\
\hline \multirow{3}{*}{$\begin{array}{l}\text { LSD at } \\
5 \%\end{array}$} & A & 0.01 & 0.03 & 0.01 & 0.04 & 0.04 \\
\hline & $\mathrm{B}$ & 0.05 & 0.01 & 0.02 & 0.03 & 0.04 \\
\hline & $\mathrm{AB}$ & 0.07 & 0.02 & 0.03 & 0.04 & 0.06 \\
\hline
\end{tabular}

Notes: Values in the same row with different superscripts are statistically significant from each other $(p<0.05)$.

increasing percent of broken faba bean seeds in manufactured samples of Saidy Kishk led to increase total bacterial count and Lactic acid bacteria count. These results are nearly in according with those found by Abdelgadir et al., (2001). Osborne \& Edwards, (2007); Akabanda et al., (2010) and Ahmed et al., (2014) pointed out that responsible for the secretion of organic acids and lowering $\mathrm{pH}$ is lactic acid bacteria. The $\mathrm{pH}$ value of kishk decreased gradually throughout the production at the end of drying process. At the end of drying step and manufacturing period, as expected, moisture content of kishk samples were sharply decreased, which is suitable for long-term storage without deterioration (Gurbuz et al., 2010). At the beginning of the fermentation, initial counts of yeasts were lower than thermophilic and mesophilic LAB counts. Finally, no molds or coliforms were detected in any kishk sample in the study. This is indicating no contamination occurred from environment and raw materials. The production of organic acids from lactic acid bacteria during fermentation stage is the cause to low $\mathrm{pH}$ value, which had an antimicrobial effect on several pathogens (Herken \& Çon, 2014). Consequently, at the end of the fermentation the predominant micro-organisms compared to yeasts of kishk samples are mainly a lactic acid bacterial, were LAB populations. On the other hand, in the same Table, the data indicated that type of milk i.e., full cow milk, skimmed milk and Laban Zeer had the real effect on total bacterial count and Lactic acid bacteria count of Saidy Kishk samples. Samples of Saidy Kishk prepared from skimmed milk contained the lowest values of total bacterial count (5.74 $\log \mathrm{CFU} / \mathrm{g}$ ) and Lactic acid bacteria count (4.54 log CFU/g), and the highest values (8.55 and $7.22 \mathrm{log}$ $\mathrm{CFU} / \mathrm{g}$ ) were found in Saidy Kishk samples prepared from Laban zeer, respectively. 
This might be attributed to that microbial load of Laban zeer was the highest. It is noteworthy here to mention that microbial populations of samples decreased gradually due to the increase in acid content and formation of components such as carbon dioxide, hydrogen peroxide, diacetyl, ethanol and bacteriocins (Erbaş et al., 2005). These findings are in harmony with those recorded by Akabanda et al., (2010), Ahmed et al., (2014). Significant interactions between cereal formula (type and percent of cereal) and milk type used in the manufacture regarding microbial quality of Saidy Kishk samples except Coliform bacteria count and molds \&yeast count were shown in Table, 6. Saidy Kishk samples manufactured from $100 \% \mathrm{~B}$ with skimmed milk had the lowest values of total bacterial count (4.65 log CFU/g) and Lactic acid bacteria count (3.26 $\log \mathrm{CFU} / \mathrm{g}$ ). These findings are in rather close accordance with that reported by Akabanda et al. (2010), Ahmed et al., (2014). Drying of kishk resulted finally in a decrease of all LAB counts of several $\log$ units, owing to the decreasing moisture content of the product (Sengun et al., 2009).

3.3. Sensory quality of Saidy Kishk: Sensory panel quality is main indicator of potential consumer preferences and most closely linked to the choice of food products. Taste, appearance, flavor, texture, and overall acceptability properties were evaluated as sensory characteristics in Table, 7 . The results obtained showed that formula (type and percent) of cereal had a significant effect on all previous properties of Saidy Kishk samples. Samples manufactured with replacing bulgur by $50 \%$ of broken faba bean seeds $(50 \% \mathrm{~B}+50 \% \mathrm{Fb})$ contained the highest values of Taste (22.61), appearance (21.22), flavor (22.11), texture (21.85) and overall acceptability (87.80). Conversely, Saidy Kishk manufactured from $100 \%$ B scored the lowest values of Taste (20.20), appearance (20.39), flavor (21.15), texture (19.57) and overall acceptability (81.32). Such differences might be due to the variation of protein content of burghul and faba bean. These results are in good agreement with those reported by Ibanoglu et al., (1995) and Muir, et al., (2000). They indicated that color properties of kishk samples were different when using different types of cereal. LAB microorganisms are playing major role in the generation of aromatic compounds typical for the final product (Gursoy et al., 2013). On the other hand, in the same Table, the data indicated that type of milk i.e., full cow milk, skimmed milk and Laban Zeer had a real effect on sensory evaluation properties i.e., Taste, appearance, flavor, texture and overall acceptability properties of Saidy Kishk samples. Samples of Saidy Kishk prepared from skimmed milk contained the highest values taste (22.43), flavor (21.97), texture (21.02) and overall acceptability (86.79) as well as the lowest value of appearance (20.80). These findings are in harmony with those recorded by Gursoy et al., (2013). They indicated that samples of kishk were brighter when using skimmed milk, since it did not contain any $\beta$-carotene pigment. Significant interactions between cereal formula (type and percent of cereal) and milk type used in the manufacture regarding sensory quality of Saidy Kishk samples were shown in Table, 7. Saidy Kishk samples manufactured from $50 \% \mathrm{~B}+50 \mathrm{fb}$ with skimmed milk had the highest values of Taste (23.35), flavor (22.91), texture (22.34) and overall acceptability (90.03). These findings are in rather close accordance with that reported by Gursoy et al., (2013). They concluded that milk type affected color parameters of kishk samples.

Conclusion: This study concluded that Saidy Kishk samples manufactured from $50 \% \mathrm{~B}+50 \% \mathrm{Fb}$ with skimmed milk had the highest values of threonine $(3.75 \%)$, leucine $(10.91 \%)$, lysine $(6.47 \%)$, phenylalanine (5.33\%), valine $(4.88 \%)$, histidine $(3.11 \%)$, $\mathrm{Ca} \quad(319.67 \mathrm{mg}), \quad \mathrm{Mg} \quad$ (172.00mg), K (1117.67mg/100g DWB) and Fe (7.19ppm). Therefore, it is suggested that this formula of Saidy Kishk samples could be used to increase the nutritional value and added value viewpoint of economical and nutritional. 


\author{
Abbreviations \\ AOAC: Association of Official Analytical \\ Chemists \\ DPPH: 2,2-Diphenyl-1-picrylhydrazyl \\ TBC: Total bacterial count \\ LAB: Lactic acid bacteria \\ FAO: Food and Agriculture Organization \\ WHO: World Health Organization \\ UNU: United Nations University \\ CFU: Colony forming unit \\ DWB: Dry weight basis \\ FW: Fresh weight
}

\section{REFERANCES}

Abd El-Ghani, S., Wafaa, K. Bahgaat \& M.T. Fouad (2014). The microbiological quality and physiochemical attributes of Egyptian traditional Saidy Kishk. J. Food Industries \& Nutr. Sci., 4(1),13-21.

Abd El-Salam, M. (2003). Fermented milks: Middle East, in.: Encyclopedia of dairy sciences. Academic Press, London, 10411045.

Abdelgadir, W. S., Hamad, S. H., Møller, P.L. \& Jakobsen, M. (2001). Characterization of the dominant microbiota of Sudanese fermented milk Rob. Int. Dairy J. 11, 6370.

Abou-Donia, S. A. (2008). Origin, history, and manufacturing process of Egyptian dairy products: An overview. J. Food Sci. Technol. 5, 51-62.

Abou-Zeid, Nadia, A. (2016). Review of Egyptian cereal-based fermented product (Kishk). International Journal of Agriculture Innovations and Research 4(4), 2319-1473.

Ahmed, L. I., Morgan, S. D., Hafez, R. S. \& Abdel-All, A. A. A., (2014). Hygienic quality of some fermented milk products. Int. J. Dairy Sci. 9, 63-73.

Akabanda, F., Owusu-Kwarteng, J., Glover, R. L. K. \& Tano-Debrah, K. (2010). Microbiological characteristics of Ghanaian traditional fermented milk product, Nunu. Nat. Sci. 8, 178-187.

AOAC (2017). Official methods of Analysis. Association of Official Analytical, Chemists $20^{\text {th }} \mathrm{ed}$., Maryland., U.S.A.
Atamian, S., Olabi, A., Kebbe Baghdadi, O., \& Toufeili, I. (2014). The characterization of the physicochemical and sensory properties of full-fat, reduced-fat and lowfat bovine, caprine, and ovine Greek yogurt (Labneh). Food Science \& Nutrition, 2(2), 164-173.

Bahgaat, Wafaa K. \& S. Abd El Ghani (2017). Comparison of amino acids and fatty acids profiles of Egyptian kishk: Dried wheat based fermented milk mixture as functional food. Am. J. Food Technol., 12 (1): 43-50.

Beal, C. \& Sodini, I., (2003). Fabrication des yaourts et des laits fermentés. Tech. Ing. Bioprocédés TI140.

Çelik, I., Isik, F. \& Yilmaz, Y., (2010). Chemical, rheological, and sensory properties of tarhana with wheat bran as a functional constituent. Akad. Gida 8, 1117.

Corrieu, G., \& Luquet, F. M. (2005). Bactéries lactiques et probiotiques, édition Tec. et Doc. Lavoisier, Paris France.

El.Fiel, W.E.A., A.H. El.Tinay \& E.A.E. El.Sheikh (2002). Effect of nutritional status of faba bean (Vicia faba, L.) on protein solubility profiles. Food Chem., 76, 219- 223.

Erbaş, M., Certel, M. Kemal \& Uslu, M. (2005). Microbiological and chemical properties of Tarhana during fermentation and storage as wet sensorial properties of Tarhana soup. LWT -Food Sci. Technol., 38, 409-416.

Erkan, H., Çelik, S., Bilgi, B., \& Köksel, H. (2006). A new approach for the utilization of barley in food products: Barley tarhana. Food Chemistry, 97(1), 12-18.

Erkaya, T. \& Sengül, M. (2011). Comparison of volatile compounds in yoghurts made from cows', buffaloes', ewes', and goats' milks. Int. J. Dairy Technol. 64, 240-246.

Gurbuz, O., Gocmen, D., Ozmen, N. \& Dagdelen, F., (2010). Effects of yeast, fermentation time, and preservation methods on Tarhana. Prep. Biochem. Biotechnol. 40, 263-275.

Gursoy, O., Kesenkas, H. \& Yilmaz, Y. (2013). White cheese, in: Handbook of 
Cheese in Health: Production, Nutrition and Medical Sciences. Wageningen Academic Publishers.

Hassan, Manal

A.M. (2019).

Physicochemical,

nutritional

characteristics and phenolic acids fractionation from some cultivars of faba bean (Vicia faba, L.) seeds. World Journal of Dairy \& Food Sciences 14 (2): 174-184.

Herken, E. N. \& Çon, A. H. (2014). Use of Different lactic starter cultures in the production of Tarhana: Latic starter cultures in Tarhana production. J. Food Process. Preserv. 38, 59-67.

Ibanoglu, S., Ainsworth, P., Wilson, G. \& Hayes, G. D. (1995). The effect of fermentation conditions on the nutrients and acceptability of Tarhana. Food Chem. 53, 143-147.

Mohammed, H.E.H., A.E.E. Suliman, A.A. Ahmed \& M.A. Ebrahim (2020). Ultraviolet effect on faba bean seed quality during storage. Asian J. Plant Sci., 19 (1): 26-34.

Montgomery, D. C. (2017). Design and analysis of experiments. John wiley \& sons.

Muir, D. D., Tamime, A.Y. \& Khaskheli, M., (2000). Effect of processing conditions and raw materials on the properties of Kishk 2. sensory profile and microstructure. $L W T$ Food Sci. Technol, 33, 452-461.

Nassar, K.S., Shamsia, S. M. \& Attia I. A. (2016). Improvement of the nutritional value of a cereal fermented milk: 2 -dried Kishk like. J. Food, Process Technol 7: 638, 7 (11) 1-7.

Osborne, J. P. and Edwards, C. G. (2007). Inhibition of malolactic fermentation by a peptide produced by Saccharomyces cerevisiae during alcoholic fermentation. Int. J. Food Microbiol. 118, 27-34.

Robinson, R. K., Lucey, J. A., \& Tamime, A. Y. (2006). Manufacture of yoghurt. Fermented milks, 53-75.

Salameh, C. \& C. Hosri (2016). Evaluation of the hygienic quality and nutritional value of traditional Lebanes e "Kishk", a dried fermented goat milk product. Options
Méditerranéennes, Série A. Séminaires, 115, 169- 173.

Sengun, I.Y., D. S. Nielsen, M. Karapinar \& M.Jakobsen (2009). Identification of lactic acid bacteria isolated from Tarhana, a traditional Turkish fermented food. Int. J. Food Microbiol., 135: 105.

Shevade, A.V., Y.C. O'Callaghan, N.M. O'Brien, T.P. O'Connor \& T.P. Guinee (2018). The proportion of fermented milk in dehydrated fermented milk-parboiled wheat composites significantly affect their composition, pasting behaviour, and flow Properties on reconstitution. Foods, 7, 113, 1-16.

Tamer, C.E., A. Kumral, M. Aşan \& İ. Şahin (2007). Chemical compositions of traditional tarhana having different formulations. J. Food Process. Pres., 31, 116.

Yildiz, F. (2016). Development and manufacture of yogurt and other functional dairy products. CRC press.

Zmudzi, D., U. Goik \& P. Ptaszek (2021). Functional and rheological properties of Vicia faba, L. protein isolates. Biomolecules, 11, 178,1-17. 